\title{
Commercialized Intercollegiate Athletics: A Proposal for Targeted Reform Consistent with American Cultural Forces and Marketplace Realities
}

\author{
Matthew J. Mitten \\ James L. Musselman \\ Marquette University Law School South Texas College of Law
}

\author{
Bruce W. Burton \\ Charlotte School of Law
}

This article observes that American society's passion for intercollegiate sports competition is an extremely powerful, naturally evolved cultural force. The marketplace responds to cultural forces, and the commercialization of college sports directly reflects the marketplace realities of our society. For example, colleges and universities rationally use their intercollegiate athletic programs, particularly NCAA Division 1 FBS football and basketball, as a means to achieve a wide range of legitimate objectives of higher education. Thus, the authors advocate that university athletic department revenues should continue to be exempt from federal taxation, specifically the unrelated business income tax (UBIT), despite the increasingly commercialized nature of intercollegiate sports. However, the commercialization of intercollegiate athletics creates the potential for conflict with a university's academic mission and the risk that student-athletes may be exploited. The authors propose that Congress provide the NCAA and its member universities with a limited exemption from the federal antitrust laws conditioned upon targeted reforms that will 1) ensure that intercollegiate athletics are primarily an educational endeavor; 2) better enable student-athletes in revenue-generating sports to obtain the benefit of their bargain; and 3) protect and maintain student-athletes' intercollegiate athletics participation opportunities in nonrevenue generating sports.

This article begins by exploring our society's powerful, naturally evolved passion for intercollegiate sports competition, the historical evolution of this cultural phenomenon, and the role of intercollegiate athletics within the 21 st century American university along with criticisms of the commercialized model that is

\footnotetext{
Mitten is Professor of Law and Director, National Sports Law Institute, Marquette University Law School, Milwaukee, WI. Musselman is Professor of Law, South Texas College of Law, Houston, TX. Burton, semi-retired Professor of Law, is currently a Visiting Professor of Law at Charlotte School of Law, Charlotte, NC.
} 
prevalent today. The United States marketplace responds to cultural forces and strong public demand for popular products; the commercialization of college sports directly reflects the marketplace realities of our society. For example, in response to substantial public interest in intercollegiate sports, particularly Division 1 Football Bowl Subdivision (FBS; formerly Division 1-A) football and men's basketball, colleges and universities rationally invest substantial resources in their athletic departments, as a means to achieve a wide range of legitimate objectives that further their missions: providing a lens through which the nature, scope, and quality of their higher educational services is discovered by the public; attracting faculty, students, and student-athletes; diversifying their student body; forging a continuing bond with alumni, the local community, and other constituents that provides both tangible and intangible benefits; and enhancing their institutional reputations.

We then explain why university athletic department revenues should continue to be exempt from federal taxation, specifically the federal unrelated business income tax (UBIT), despite the increasingly commercialized nature of intercollegiate sports such as Division 1 FBS football and men's basketball. Moreover, proposed revision of federal tax law is not an effective means of preventing marketplace forces from pushing intercollegiate athletics out of its proper role as an integral part of nonprofit higher education and into a primarily commercial endeavor nearly identical to for-profit professional sports.

Recognizing that the commercialization of intercollegiate athletics creates economic incentives for conduct that may conflict with a university's academic mission and may potentially exploit student-athletes, we propose that Congress provide the National Collegiate Athletic Association and its member universities with a conditional exemption from the federal antitrust laws. This limited antitrust immunity would enable the NCAA to enact legislation to ensure that intercollegiate athletics is primarily an educational endeavor and to prevent the excessive allocation of university financial resources to sports as well as to better enable student-athletes in revenue generating sports to obtain the educational benefits of their bargain. In addition, our proposal has the potential to protect and maintain student-athletes' intercollegiate athletics participation opportunities in sports that do not generate net revenues.

\section{Commercialized Intercollegiate Athletics Reflects Cultural Forces and Marketplace Realities}

\section{The Psychological, Cultural, and Economic Underpinnings of Intercollegiate Athletics}

The history of sport reveals underlying primal forces inherent in athletic competition-humanity's youthful energy and an inherent desire, based largely on an innate survival instinct, to compete with one's fellows (Bonime, 1986). This evolved motivation, when combined with the symbiotic, often passionate relationship between the athletic teams of a college or university and its broad variety of powerful constituencies, triggers a marketplace dynamic that reflects both basic human nature and its expression in American culture. The commercialization of intercollegiate athletics, which has steadily increased over time, is a natural response 
to these cultural and market conditions that reflect human nature and the mindset of the leaders of American institutions of higher education.

Current neurology and psychology research indicates that human play is a joyproducing essential activity of our species - an evolved, natural survival element inherent in humans (and certain other mammals) (Brown, S., 2009). Thus viewed, today's mega-intercollegiate athletics did not begin with institutional athletic departments, high-priced coaching staffs, alumni supporters, Nike and other commercial licensees, ESPN and other sports broadcasters, and Sports Illustrated and other media sources. Athletic competition is rooted deeper in us; it is part of the robustness of America's settlers-for example, a youthful Abe Lincoln reportedly first gained notice for his strength and athletic ability in frontier Indiana wrestling contests (Norton, 2009; Beskow, 1987). This same primal energy is the source of intercollegiate sports competition; for example, the 1852 regatta between Harvard and Yale students, which was the first large scale intercollegiate athletics event among American universities (Davenport, 1999).

The long history of human athletic competition illustrates something fundamental about American character. Like psychologist-neurologist-researcher Stuart Brown, we might devote decades to studying play activities among the young (Brown, S., 2009). We would observe clusters of preschoolers romping together in public parks; stickballers on inner-city streets; hoopsters in every neighborhood scrambling for rebounds; kids' racing on elementary school playgrounds; rural teens with gloves, mitts, and baseballs in grassy meadows every spring. We also would see prepubescent boys and girls competing as members of suburban teams in leagues from coast-to-coast as well as groups of ten-year-olds playing in Pop Warner football leagues. A powerful, elemental spark exists in youth that hungers for the adventure of athletic competition. Assuming this thirst for competition and choosing up sides - team loyalty_are closely linked, the mere existence of competitive intercollegiate teams energizes enthusiasm among those who are spectators to the competition.

Regardless of how one views the existence of our competitive nature-whether you celebrate the individual drive to compete or condemn it as a barrier to a more utopian ideal based on sharing and cooperation-this seems clear: The presence of our primal competitive drive is not a contrivance by marketplace forces but, conversely, an evolved, natural survival element. As always, our culture reflects human needs for expression of our innate drives and, in a free market system, the marketplace responds to cultural demands and gives rise to commercialization. Intercollegiate athletics are a powerful example.

\section{The Evolution of Commercialized College Sports: 1852-Present}

Historically, intercollegiate sports competition has never been insulated from the impact of American culture, both academic and general. Rather, it always has been an integral and representative part of our culture. Briefly reviewing the principal cycles in the evolution of American intercollegiate athletics will help to clarify this article's central proposition: Elemental forces of human nature create cultural desires, which are quickly satisfied by the creation of products and services through the operation of a free marketplace. This ongoing dynamic creates powerful 
economic forces with corresponding commercial incentives that create the potential for social and political conflicts as well as abuses. The evolution, growth, and commercialization of intercollegiate athletics - with the predictable conflicts and abuses - is a paradigmatic example of these cultural and marketplace phenomena in action (Davenport, 1999).

As a threshold matter, it is important to recognize that the nostalgic characterization of American intercollegiate sports as "amateur" athletic competition is not an accurate depiction of either historic or current reality. Athletic competition among American institutions of higher education was, from an early date, based on the British rhetoric of "amateurism." The erroneous ideal of uncompensated competitive sport for its own sake, which purportedly was the nature of athletic competition in Ancient Greece, did not reflect reality because successful Greek athletes were paid substantial sums of money for their efforts (reportedly up to "ten years worth of wages") (Shropshire, 1991). Nevertheless, this historically mistaken notion of "amateurism" became the hallmark of elite British universities such as Cambridge and Oxford and flourished by reason of English society's rigid class distinctions and culture of elitism (Turano, 2009). The concept of "amateurism" has been a hypocrisy masking the reality of American interscholastic athletics from its earliest moments. It is notable that the first of this country's intercollegiate sports rivalries arose in 1852 antebellum America with crew competitions between students from Harvard and Yale. Harvard rowing teams from the 1850s onward were known to participate for the payment of sums ranging from $\$ 100$ to $\$ 500$ (Shropshire, 1991).

Subsequent commonplace practices such as awarding athletic scholarships covering the costs of student-athletes' tuition, room, board, and books that are worth thousands of dollars, hiring professional coaches (including multimillion dollar salaries for Division 1 FBS and men's basketball teams) and athletic trainers, recruiting talented athletes, and generating multimillion dollar revenues from gate receipts, broadcast revenues, and sponsorships are notable features of the commercialization of American intercollegiate athletics, which belies the truth of its continuing self-characterization as "amateur" sports competition.

The pattern of competitive intercollegiate athletics since 1852 has been akin to the history of America itself. As part of the never-ending dynamics of human activity, athletic competitions between student groups from rival institutions of higher education became more commonplace. The first intercollegiate football game was played by teams of students from Rutgers and Princeton in 1869 (Kennedy, 2000). As in all things human, unintended negative side effects and problems inevitably arose. With the result that leaders of higher education institutions sought to jointly regulate football contests and other competitive student athletic activities, which were burgeoning in popularity. For example, to deal with violent brawls and other problems, the famed 1895 Chicago Meeting led to the formation of The Big Ten as the nation's first major intercollegiate athletics conference (Davenport, 1999).

The next important landmark came in 1905 when serious college football injuries and deaths rocketed to epidemic proportions. President Theodore Roosevelt reacted by meeting with Ivy League institutions and demanded reform of football's playing rules to remedy this problem (Alesia, 2006). In response, the representatives of sixty-two major institutions met to form the Athletic Association of the United States (AAUS), the predecessor to the National Collegiate Athletic Association (NCAA). 
During the 1920s intercollegiate athletics became formally recognized as part of higher education under the auspices of the NCAA (Carter, 2006). In this era the linkage between alumni and the institution-reflecting institutional thirst to obtain financial support from donors-became firmly tied to many universities' intercollegiate sports programs. The market crash of 1929 coincided with the release of the Carnegie Report, which summarized the detailed findings of its multiyear project examining the nature of athletic competition and its relationship to college administrators arising from the sports boom of the 1920s (Davenport, 1999). The Carnegie Report documented "rampant professionalism, commercialization, and exploitation that were corrupting virtually all aspects of intercollegiate athletics" (Griffith, 1930). The litany of abuses identified in the Carnegie Report included the inordinate emphasis on intercollegiate sports competition on college campuses and failed university administrative oversight of football programs, plus particularized lists of many institution-specific bad practices. To remedy such abuses, the Carnegie Report called for reform to eliminate commercialization and professionalism in intercollegiate athletics (Savage, 1929). However, even during the general economic belt-tightening of the Great Depression, these problems continued largely unabated.

After the World War II interregnum came a rocketing resurgence of college sports - and the advent of national TV — as college athletic departments became sources of significant revenue. Money, usually tied to winning programs, became the driving force in athletic departments; recruiting abuses, basketball scandals, and other distressing events were rampant (Davenport, 1999). In response, the NCAA was transformed from an advisory body into a powerful national regulatory agency, which made rules, systematized policing of rules infractions, and imposed sanctions on its member institutions for rules violations (Smith, 2000). The NCAA was authorized by its member schools to censure, penalize, expel, and enforce sanctions against institutions for rules violations that contravene its basic objective "to maintain intercollegiate athletics as an integral part of the educational program and the athlete as an integral part of the student body and, by so doing, retain a clear line of demarcation between intercollegiate athletics and professional sports" (NCAA Constitution, article 1.3.1).

For the past 60 years, the commercialization of intercollegiate sports has continued to grow, largely in response to the enormous popularity of Division 1 FBS football and men's basketball and the consequent multimillion dollar revenue generating potential of these sports. For instance, CBS agreed to pay the NCAA \$6 billion from 2002 through 2013 to broadcast its men's basketball tournament. A May 2009 Congressional Budget Office (CBO) paper titled "Tax Preferences for Collegiate Sports" states that the 2008 NCAA men's basketball tournament generated approximately $\$ 143$ million in revenue for college athletic departments and that FBS bowl games generated roughly the same amount (Congressional Budget Office, 2009). The CBO paper includes data showing that the 2004-05 fiscal year average athletic program revenues for universities with Division 1 FBS football and men's basketball teams was $\$ 35.2$ million.

According to a February 2009 study commissioned by the NCAA titled "The Empirical Effects of Collegiate Athletics: An Update Based on 2004-2007 Data," Division 1 athletic departments with FBS football and men's basketball teams increased their spending by an average of almost $10.7 \%$ annually from 2004 to 07 with their annual revenues increasing by $10.6 \%$, which evidences roughly a 
one-for-one relationship between athletic expenditures and revenues (NCAA, 2009). (This increased spending on intercollegiate athletics was more than double the average $4.9 \%$ annual increase in these universities' overall nonathletics spending during this time period.) The study also found data that supports the existence of an "arms race" (i.e., "a situation in which the athletic expenditures by a given school tend to increase along with expenditures by other schools in the same conference") at this level of intercollegiate athletics competition. Although the annual salaries of many football and basketball coaches exceed $\$ 1$ million, the study found no significant relationship between coaching salaries and the team's winning percentage.

A report concerning the 2004-06 NCAA Revenues and Expenses of Division 1 Intercollegiate Athletics Programs found that only 19 of 119 Division 1 FBS institutions generated revenues that exceeded their expenses in the 2006 fiscal year (NCAA, 2006). From 2004-06, only 16 institutions reported positive net revenues. For 2006 salaries for coaches (17\%) and administrators (15\%) accounted for $32 \%$ of total expenses. The 2006 median salary for basketball head coaches was $\$ 611,900$ (a 15\% increase from the 2004 median); for football head coaches it was $\$ 855,500$ (a 47\% increase from the 2004 median). Total athletic department spending is approximately $5 \%$ of total university expenses at median FBS institutions.

\section{Role of Intercollegiate Athletics Within 21st Century American Universities and Academic Criticism of its Prevalent Commercial Model}

At its core, the efforts of many college and university presidents to invigorate their campuses involves building their academic and research programs, attracting topnotch faculty and larger incoming classes of students with stronger academic credentials, generating more donations and bigger endowments, reconfiguring their institutional identities, and enhancing their institutions' political clout. In an extremely competitive higher education market, academic leaders increasingly use intercollegiate sports as a catalyst and means to achieve these legitimate ends. This rational conduct on the part of university presidents and governing boards is merely a facet of competition in a well-functioning democratic society. This is a drive embedded in human nature and modern culture, which is embodied by the centuries' old American enterprising spirit of doing what is necessary to compete successfully.

Regarding the similarities between intercollegiate athletics and higher education, Sidney McPhee, the president of Middle Tennessee State University, explained: "Competition among institutions of higher education may be perceived as being confined to the playing field. It is not. While we tend to think of higher education as a homogeneous collection of colleges and universities, individually they are varied and aggressively competing with one another for resources, talent and standing.... Competition on the playing field as is higher education is a fundamental principle of a free-enterprise system" (NCAA, October 2006, p. 23).

Universities allocate funds to intercollegiate athletics based on their perceived institutional value, which is the same way resources are allocated to their academic programs and other activities. The most prominent features found in the following examples of institutional success stories (e.g., stronger faculty recruitment, larger student bodies with better academic credentials, more financial resources, statewide 
political clout, etc., created in large part by devoting increased resources to intercollegiate athletics) all share one crucial commonality. University leaders perceived a symbiotic interdependence between a successful intercollegiate athletics program and institutional academic growth as an energizing reality in 21st century American higher education, and acted upon it (Morgan, 2007). This is the very same ladder to success by which many of the nation's currently well-established universities (e.g., Notre Dame, Michigan, Ohio State, Minnesota, and the University of Southern California) ascended long ago (Sperber, 1993).

Academic leaders from Boise State University report that the football team's recent national success has generated a huge increase in the university's pool of admissions applications. Major gifts have flowed into the campus for new business schools, nursing departments, and huge cash gifts from a prospering campus bookstore. In the past at funding time, the Idaho Legislature viewed Boise State as the fourth-best university in the state, but now recognizes it as "the first university people think of when they think of Idaho." Merchandising contracts, bookstore profits, royalties from team name licensing, Nike jersey sales, and orders for game films have boomed. Officials believe that the energizing bounce to the school and to the community of Boise "will pay off for years" (Steeg, 2007).

A decade ago the University of South Florida, which was engaged in intense competition with the University of Florida, the University of Miami, and Florida State University for graduates of Florida high schools, studied its competitive situation and decided to take several steps to enhance the success and visibility of its intercollegiate athletics program, most notably football (Emerson, A., 2007; Thrash, R. 2007). USF President Judy Genshaft makes the point, accepted by college administrators for over a century, that a winning athletics program helps an institution in its efforts to recruit top faculty members and market its academic programs to prospective students. As a result, the University of South Florida has enjoyed phenomenal growth in its student body; in five years its enrollment increased from 39,000-45,000, now making it Florida's third largest public university. Moreover, increased applications have enabled USF to be more selective in its student admissions decisions.

Georgia State University (GSU) President Carl V. Patton believes that creating a competitive intercollegiate football program is "desirable if not close to mandatory" as the GSU campus transforms itself from a commuter school to an institution that provides a "full-rounded college education" (Lederman, 2008). According to Patton, what prospective GSU students mean when they want GSU to be a "real' university. . . is a university that has successful sports programs and football is one of the things they want." Patton found widespread support among GSU alumni, students, and staff for implementation of his strategy. GSU's game plan included hiring Bill Curry, formerly the head coach at Alabama and Georgia Tech, to be the university's first head football coach (Awtrey, 2008). Similarly, the University of Houston, in an effort to reconfigure itself into a more nuclear campus by shifting away from its historic commuter culture, is utilizing on-campus football games and a recent conference championship to generate an identity change.

NCAA member educational institutions outside of Division 1 have also relied on intercollegiate athletics as a means of revitalization or transformation. Adrian College, a moribund liberal arts college in Michigan, used intercollegiate athletics 
to completely turn itself around in three years. Before 2005 Adrian's administration and faculty despaired because of their slumping enrollment and campus malaise. They decided to use intercollegiate athletics as recruiting tool in an attempt to reverse the decline and "discovered the fountain of youth for small liberal arts colleges" (Sander, 2008). Since 2005 Adrian's enrollment has surged 57\% to its highest number $(1,470)$ in twenty years and the academic caliber of students has shot up. Before 2005 Adrian had accepted 93\% of its pool of 1,200 applicants. Since adopting its athletics-based student recruiting strategy, Adrian now accepts only $72 \%$ of the applicants from a nearly fourfold larger pool of 4,200 applications and reports that its student body has better academic credentials.

Roosevelt University, a private university in downtown Chicago, is restoring its intercollegiate athletics program after a nearly 20-year hiatus (Moltz, 2009). During the past decade the university has transitioned from a largely commuter institution with adult part-time students to a more residential school with an increasing number of full-time traditional-aged students, many of whom want the university to bring back intercollegiate athletics. With the approval of Roosevelt's faculty, university administrators are embarking on a plan to create twelve sports teams (not including football), to resume participating in intercollegiate athletics competition in fall 2010, and to rejoin the National Association of Intercollegiate Athletics. After five years, Roosevelt plans to apply for admission to NCAA Division III.

The symbiotic linkage between a university's athletic success and visibility and its overall prominence and broader interests generally seems better recognized and more accepted by university presidents than by faculty members. As always, today's university chief executive officers must act amid the slings and arrows of critics. Ever since fierce intercollegiate football rivalries emerged in the late 19th century, with its accompanying flood of injuries and other problems, the existence of intercollegiate sports competition has been periodically challenged, often by clusters of university faculty members.

Critics view today's commercialized intercollegiate athletic programs as a campus leviathan, which is fundamentally inimical to the core academic values of the institutions of higher education which house them. This sentiment is based on two underlying fallacies: 1) an assumption that American universities are somehow capable of existing in isolation from the marketplace dynamics generated by powerful cultural forces; and 2) a failure to recognize and appreciate that intercollegiate athletics, despite steadily increasing commercialization, has been a part of American universities for more than 150 years.

Despite concern expressed by faculty members about a perceived unhealthy, parasitic linkage between intercollegiate athletics and institutions of higher education, many universities have increased their student enrollments and alumni pride by promoting and achieving athletic success on the football field. The use of intercollegiate sports by university leaders-who must explore all options in an effort to increase the human, financial, and other resources needed by their institutions, as part of their efforts to enable their respective institutions to flourish in an increasingly competitive higher education environment - is a rational response to marketplace realities. However, college and university presidents must not allow commercialized intercollegiate athletics to assume a role inconsistent with an institution of higher education's core values and academic mission. 


\section{University Athletic Department Revenues Should Remain Exempt From Federal Taxation}

Some commentators have taken the position that the increasing commercialization of college and university athletic programs requires that federal tax laws pertaining to those programs should be reexamined and ultimately modified by Congress. Specifically, they argue that many intercollegiate athletic programs, particularly those with Division 1 FBS and men's basketball teams, have become large and profitable businesses insufficiently related to education; as a result, they assert that Congress should reexamine whether college and university athletic programs, as well as the NCAA, should be entitled to exemption from federal taxation and/or from the federal unrelated business income tax ("UBIT") (Morgan, 2007).

\section{Federal Tax Exemption}

Organizations described in section 501(c)(3) of the Internal Revenue Code (IRC) are exempt from the federal income tax (I.R.C. §§ 501(a) and 501(c)(3)). Organizations qualifying for tax-exempt status also qualify under section 170 for deductibility by individual taxpayers of contributions made to such organizations (I.R.C. § 170). IRC section 501(c)(3) includes institutions which are organized and operated exclusively for a number of specified purposes, two of which are education and "foster[ing] national or international sports competition (but only if no part of its activities involve the provision of athletic facilities or equipment)" (I.R.C. § 501(c)(3)).

To qualify for tax-exempt status, an organization must meet a number of requirements. First, its articles of organization must meet two requirements: (1) they must limit the purpose of the organization to one or more of the exempt purposes listed in section 501(c)(3) of the IRC; and (2) they must not expressly empower the organization to engage in activities which are not in furtherance of one or more of such exempt purposes, unless such activities are an insubstantial part of such organization's activities as a whole (Treas. Reg. § 1.501(c)(3)-1(b)(1)(i)). Second, the organization must be operated exclusively for one or more of the exempt purposes listed in section 501(c)(3) of the IRC. It will be regarded as meeting this requirement if it engages primarily in activities which accomplish one or more of those purposes. It will not be so regarded if "more than an insubstantial part of its activities is not in furtherance of an exempt purpose" (Treas. Reg. § 1.501(c)(3)$1(c)(1))$. An organization may operate a trade or business as a substantial part of its activities and yet meet the requirements of section 501(c)(3) if "the operation of such trade or business is in furtherance of the organization's exempt purpose or purposes and if the organization is not organized for the primary purpose of carrying on an unrelated trade or business, as defined in section 513" of the IRC. Determining the primary purpose for which an organization is organized requires an examination of all the circumstances involved, "including the size and extent of the trade or business and the size and extent of the activities which are in furtherance of one or more exempt purposes" (Treas. Reg. § 1.501(c)(3)-1(e)(1)). No serious argument has been made that the NCAA does not meet these requirements. Likewise, no serious argument has been made that any college or university does not meet these requirements because of its athletic program. 
Two other issues are potentially relevant with regard to whether a college or university operating an athletic program qualifies for tax-exempt status under section 501(c)(3): the "private inurement" and "private benefit" limitations. Section 501(c)(3) provides that "no part of the net earnings of [an exempt organization shall inure] to the benefit of any private shareholder or individual" (I.R.C. § 501(c)(3)). This language has been interpreted "as prohibiting a 'siphoning off' of the assets of an exempt organization to an insider." This could occur by an exempt organization paying an unreasonable salary to an insider, thereby paying more than fair market value for the services that the insider provided in exchange for such salary (Colombo, 2009 p. 12). The issue that has been occasionally debated with regard to college and university athletic programs is whether the compensation packages awarded to football and basketball coaches by some schools have become sufficiently excessive so as to violate this limitation. Professor John Colombo argues persuasively that there is no real issue here, primarily because the Regulations allow reasonableness of compensation to be "measured by what the market is paying for similar services including the for-profit market." This allows for the compensation of college coaches to be compared with the compensation of coaches in the professional leagues to determine what is reasonable (Colombo, 2009 p. 13). As a consequence, it has not been seriously argued that the tax exemption of a college or university is at risk under the private inurement limitation based on the amount of compensation it pays its coaches.

The Regulations pursuant to section 501(c)(3) provide that "it is necessary [to qualify for exemption] for an organization to establish that it is not organized or operated for the benefit of private interests such as designated individuals, ... shareholders of the organization, or persons controlled directly or indirectly, by such private interests" (Treas. Reg. 1.501(c)(3)-1(d)(1)(ii)). These provisions have been interpreted to mean that "an organization can lose its exemption if, as a result of serving its charitable class, it confers an excessive benefit . . . on parties outside of the charitable class." While this limitation seems somewhat similar to the private inurement limitation, "[t]he primary differences between [these two limitations] are that: (1) the private benefit doctrine can be applied to transactions with 'outsiders' (that is, independent parties who have no influence over the charity); and (2) private benefit can apply even to transactions entered into at fair market value" (Colombo, 2009 p. 15).

The private benefit limitation has been described as "a quintessential balancing test in which the benefits to private individuals or organizations as a result of a particular activity must be weighed against the charitable benefits the activity produces." If a transaction is structured such that it appears to excessively favor private interests, it will violate this limitation even though it also serves the charitable class (Colombo, 2009 p. 17).

The issue with regard to athletic programs of colleges and universities is whether those organizations, along with the NCAA, "provide excessive private benefit to television networks and the professional sports leagues in comparison to the educational benefits provided to the charitable class (e.g., the participating student-athletes)" (Colombo, 2009 p. 17-18). The argument is that the television networks receive substantial benefits in the form of profit when they televise college games, and the professional sports leagues receive substantial benefits by effectively 
utilizing the colleges and universities as training and development programs and avoiding the cost of maintaining those programs directly (Colombo, 2009 p. 18).

Professor Colombo acknowledges that this argument "seems plausible given the extraordinarily broad scope of the private benefit doctrine," but concludes that it seems highly unlikely to succeed" (Colombo, 2009 p. 18-19). He points out that the IRS has "never shown any inclination to apply the doctrine in this manner." In addition, he asserts that "the NCAA can legitimately argue that it tries to keep its distance, and tries to distance college athletes, from the pro leagues, ... [ [and reminds us that] the NCAA was not started by the professional sports leagues as a means of sloughing off their training costs to an exempt organization" (Colombo, 2009 p. 18). Finally, he argues that the television contracts entered into by the NCAA seem fairly negotiated and there is no evidence that "the NCAA or universities negligently or intentionally 'underpriced' their product to give a bigger profit margin to the networks ..." (Colombo, 2009 p. 19).

In conclusion, it has not been seriously argued that because colleges and universities operate athletic programs they are not organizations described in section 501(c)(3) of the IRC and are thus not exempt from the federal income tax, no matter how extensive and profitable those programs may be. Likewise, there has been no serious argument that the NCAA does not qualify for exemption under section 501(c)(3).

\section{Unrelated Business Income Tax}

\section{Current Status of the Law}

Before enactment of the UBIT in 1950, funds received by colleges and universities from any source were sheltered from taxation under the institution's general tax exemption (Musselman, 2003 pp. 203-04). Until the UBIT was enacted, the law "recognized only two possibilities - an organization was either entirely taxable or entirely tax-exempt." As a result, the courts generally treated activities conducted by colleges and universities as tax-exempt regardless of whether those activities were in any way related to the exempt purpose of the institution. This led colleges and universities to conclude that they could engage in business activities totally unrelated to their exempt purpose and enjoy a significant competitive advantage because their profits were exempt from tax. A famous example was New York University's ownership of the C. F. Mueller Company, a leading macaroni producer. When the IRS attempted to tax the company's profits, New York University successfully argued that the profits were exempt from taxation on the basis of its general tax exemption. Congress became concerned that the government was losing significant tax revenue from these business operations, and that business entities not owned by colleges and universities were suffering from unfair competition (Musselman, 2003 p. 204). The ultimate result was enactment of the UBIT.

The UBIT imposes a tax, at rates applicable to taxable corporations, on the "unrelated business taxable income" (UBTI) of most tax-exempt organizations, including those described in section 501(c)(3) of the IRC (I.R.C. § 511(a); Musselman, 2003 p. 204-05). In addition, public universities are specifically subjected to the UBIT (I.R.C. $§ 511(a)(2)(b))$. UBTI is generally defined as the "gross income [of] any organization from any unrelated trade or business . . . regularly carried on by [such organization], less [certain] deductions allowed . . . which are directly 
connected with the carrying on of such trade or business" (I.R.C. $§ 512(\mathrm{a})(1)$; Musselman, 2003 p. 205).

This definition requires the determination of three issues: (1) whether an activity is a trade or business; (2) whether it is regularly carried on; and (3) whether it is an unrelated trade or business. While each college or university athletic program would have to be examined on the basis of its particular facts, it is generally assumed by commentators that many college and university athletic programs constitute a trade or business because they seek profit (Musselman, 2003 p. 205; Jensen, 1987 pp. 48-49; Kaplan, 1980 p. 1449).

The Regulations provide some guidance regarding whether an activity is regularly carried on. It is generally assumed by commentators that athletic programs of colleges and universities are regularly carried on as the Regulations define that term (Musselman, 2003 pp. 206-07; Jensen, 1987 p. 50). The NCAA periodically engages in activities that undoubtedly constitute the conduct of a trade or business, such as the NCAA basketball tournament held every year in March. It is also generally assumed that those business activities are regularly carried on within the meaning of the Regulations (Colombo, 2009 pp. 29-30; Musselman, 2003 p. 207; Jensen, 1987 pp. 48-49; Kaplan, 1980 pp. 1449-50).

In enacting the UBIT, Congress was intent on addressing its concerns stated above that colleges and universities conducting trades or businesses were able to deprive the government of significant tax revenue from those business operations, and enjoy an unfair competitive advantage over commercial business entities required to pay taxes on their income. Congress could have satisfied those concerns by providing that all trades or businesses conducted by exempt organizations would be subject to the income tax laws in the same manner as commercial business entities. Instead, Congress balanced those concerns against the basic policy for exempting certain organizations from the income tax by providing that an exempt organization would be taxed only on income from trades or businesses that are unrelated to its exempt purpose.

Whether an activity is an unrelated trade or business is a difficult issue and has in recent years become more controversial with regard to college and university athletic programs. The IRC defines an unrelated trade or business as "a trade or business [of a tax-exempt organization,] the conduct of which is not substantially related... to the [organization's] exercise or performance . . . of its [exempt] . . . function" (I.R.C. $§ 513(a)$ ). The Regulations provide that a trade or business is substantially related to an organization's exempt purposes if "the production or distribution of the goods or the performance of the services from which the gross income is derived ... contribute importantly to the accomplishment of those purposes." Resolution of this issue "depends in each case upon the facts and circumstances involved" (Treas. Reg. $§ 1.513-1(d)(2))$. An important factor is the "size and extent of the activities involved" in operating the trade or business compared with the "nature and extent of the exempt function which they purport to serve." Thus, if the trade or business is "conducted on a larger scale than is reasonably necessary for performance of" the organization's exempt functions, "the gross income attributable to that portion of the activities in excess of the needs of exempt functions constitutes gross income from the conduct of [an] unrelated trade or business" (Treas. Reg. § 1.513-1(d)(3)).

In Congressional hearings considering enactment of the UBIT, the House Ways and Means Committee and the Senate Finance Committee both concluded that "income of an educational organization from [admission] to football games" 
is not subject to the UBIT because "athletic activities of schools are substantially related to [the] educational functions" of those institutions (H.R. Rep. No. 2319, p. 409; S. Rep. No. 2375, p. 505). This language has essentially given colleges and universities a free pass under the UBIT with regard to their athletic programs (Musselman, 2003 p. 207; Jensen, 1987 p. 51). The IRS made a run at college athletics in 1977, asserting that revenue from the broadcasting rights to the Cotton Bowl football game were subject to the UBIT (Musselman, 2003 p. 207; Jensen, 1987 p. $51 \mathrm{n} .68$ ). The IRS received a significantly negative reaction from the public to that attempt and responded in 1978, retracting its earlier position by issuing a series of unpublished National Office Technical Advice Memoranda discussing the close relationship of college athletics and education, and favorably comparing exhibition of a game in person with exhibition of a game on television to a much larger audience (Tech. Adv. Mem. 78-51-002; Tech. Adv. Mem. 78-51-004; Tech. Adv. Mem. 78-51-005; Tech. Adv. Mem. 78-51-006; Musselman, 2003 p. 207; Jensen, 1987 pp. 51-52 nn.68-69). In addition, the IRS issued two revenue rulings in 1980 consistent with its new position on this issue (Rev. Rul. 80-295; Rev. Rul. 80-296), stating in one such ruling that "[a]n athletic program is considered to be an integral part of the educational process of a university, and activities providing necessary services to student athletes and coaches further the educational purposes of the university" (Rev. Rul. 80-296).

\section{Should Congress Change the Law?}

In spite of such stalwart support on the part of both Congress and the IRS for exemption from the UBIT of college and university athletic programs, some commentators assert that Congress should reexamine its conclusive statement that "athletic activities of schools are substantially related to [the] educational functions" of those institutions (Morgan, 2007). For example, Gabriel Morgan has argued that college and university athletic programs have become commercial enterprises that are independent of and detached from the institution, and have departed from the educational standards and values of the colleges and universities that sponsor them (p. 176). He believes that the extreme commerciality of these programs jeopardizes the education of the student-athletes and the financial security of the university, and that the programs "actually hinder the development of student-athletes' academic capabilities in the quest for athletic victory and its accompanying revenue;" the best solution is to eliminate the Congressional presumption that college and university athletic programs are substantially related to the educational purposes of those institutions (pp. 177-79). He offers three justifications for this proposition.

First, he asserts that there is no historical justification for any such presumption. He supports this assertion by citing to sources discussing the primal stages of American intercollegiate athletics in the nineteenth and early twentieth centuries and their independence from the colleges and universities with which they were associated. In the beginning, college and university "administrations considered intercollegiate athletics wholly unrelated to a student's academic pursuits" (p. 179). It was not until the founding of the NCAA in the early twentieth century that colleges and universities asserted control over their athletic programs "by integrating them into newly created physical education departments," and the purpose of that decision was not to establish a relationship between academics and athletics, but 
rather to assert control over intercollegiate football and its "run-away violence" (p. 180). This argument does nothing more than establish that American intercollegiate athletics began in the nineteenth century in a very primitive form and gradually evolved into its modern day structure. It is of no assistance in determining whether there should presently be a presumption that college and university athletic programs are substantially related to educational purposes.

Morgan's second justification for eliminating the Congressional presumption is the commercialization of intercollegiate athletics and its focus on the generation of revenue. He believes such a focus "undermines the academic and financial integrity of both the athletic department and its university" (p. 181). He cites the introduction of television as the gateway that ultimately led to today's multibillion dollar broadcasting contracts, multimillion dollar compensation packages for coaches, and the pressurized environment created by the need to remain competitive and maximize revenue, resulting in an overemphasis of athletic success and revenue and the devaluation of education (pp. 181-82).

This premise is the subject of much debate. University administrators assert that the success of university athletic programs translates to "increased applications to the university, superior student bodies, and increased alumni donations." Morgan cites to studies that support "the notion that the success of a university's athletic department causes an increase in applicants to the university," but asserts that the data "failed to conclusively prove any relationship between athletic success and the academic quality of an incoming freshman class." He concludes that "the notion that athletic success generates indirect educational value by increasing the quality of the student body is [thus] unsubstantiated." One could also conclude from that data that the university administrators could perhaps be correct on that point. But even if there is no relationship whatsoever between a successful athletic program and the academic quality of an incoming class, increasing applications to the university by itself would constitute a significant achievement relating to the educational mission of the university. Colleges and universities constantly look for ways to increase their applicant pools for reasons other than increasing the academic statistics of the entering class; a common example would be to diversify a university's student body. Morgan also cites to a letter written to Myles Brand, president of the NCAA, from Representative Bill Thomas, chairman of the House Ways and Means Committee, for the proposition that the "federal government's purpose in granting tax exemption to universities is to further education in general, not to increase the recognition, reputation or relative quality of one individual institution" (p. 183). That argument presumes the national applicant pool is finite and competition among colleges and universities for those applicants is a zero sum game. On the contrary, a much more logical presumption is that college and university athletic competition generally attracts a significant number of applicants with a high interest in athletics who would not otherwise be interested in attending college.

As to the assertion by university administrators that successful university athletic programs result in increased alumni donations, Morgan cites to studies that have shown varying results; some "studies found no relationship between alumni donations and athletic success, others found a statistically significant relationship, and others found a relationship between athletic success and athletic donations" (p. 184). But he concludes that whether there is in fact a correlation between successful programs and increased donations is irrelevant because athletic programs are 
not always successful and thus at times fail to attract a high level of donations; the result is that very few programs are profitable and "can have tangible and deleterious effects on the financial and educational interests of a university" (p. 184-85). If it is true that very few athletic programs are profitable, it is difficult to understand why subjecting college and university athletic programs to the UBIT will have any effect whatsoever on the manner in which such programs are conducted. But aside from that observation, it is not difficult to understand why a college or university would seek to maximize alumni donations from whatever source possible to further its educational goals. If increased donations are made to the university's general fund, the educational benefits are obvious; but even if the increased donations are made only to the athletic programs, educational benefits to the university will result. As donations increase, the university will be able to increase the quality and breadth of the programs, resulting in an increase in the quality and reputation of the university.

The case studies described in this article are illustrative of the tremendous benefits, educational and otherwise, that colleges and universities have received by increasing the quality of their athletic programs; as discussed, such benefits include attracting high-quality faculty and students, generating donations and enrichment, reconfiguring their campus identities, and enhancing institutional political clout. Whether the athletic programs are profitable or not is of no consequence; there is no distinction between funding an athletic department and any other department of the university. A college or university, in its normal budgeting process, will allocate its resources based on each department's need for funds, balanced against the institution's overall objectives and goals.

Morgan's third justification for eliminating the Congressional presumption is that the academic integrity of colleges and universities will be sacrificed "by recruiting, admitting, keeping eligible, and graduating talented athletes who are unqualified for the academic rigors of college-level curricula," thereby undermining the educational purpose of the institution. (p. 186). In support of this premise, he cites to sources asserting that student-athletes are often recruited and admitted who do not satisfy the academic criteria established for students in general; that athletic departments have developed strategies to enable student-athletes to remain eligible in their sport in spite of their lack of motivation and academic ability; and that graduation rates for student-athletes are significantly below those for the student body as a whole. He asserts that these issues persist in spite of regulatory attempts at reform by the NCAA, and that they result in damage to "the intellectual ethos of a campus" and to "the educational goals of a university" (pp. 172-76 and 187).

Student-athletes are not the only group who are recruited and admitted with lower academic statistical qualifications, are the target of strategies designed to assist them in meeting academic performance standards as students, and graduate at lower rates than the student body as a whole. Admitting an entering class with the highest possible admission statistics is not the sole goal of a college admissions office. Every college and university, for example, allocates substantial resources to achieve and maintain a diverse student body, and virtually everyone would agree that accomplishing that goal significantly improves the educational environment of the institution. If athletic programs are in fact related to the educational purposes of colleges and universities, recruiting student-athletes to participate in such programs and assisting them in meeting academic performance standards would be appropriate activities in which colleges and universities should engage. Some of 
the students who are recruited and admitted for the purpose of achieving a diverse student body would not have been given the opportunity to attend college if not for the diversity they bring to campus; likewise, some students would not be given the opportunity to attend college if they were not athletes.

Morgan suggests that nonathlete applicants who are more academically qualified are rejected for admission so that athletically gifted student-athletes can be admitted, resulting in "the inefficient use of scarce academic resources" because the nonathlete applicants "would have taken greater advantage of the academic resources offered by the university" (p. 187). That is the same flawed argument used by opponents of diversity admissions programs. Academic statistics based on standardized test scores and high school grades are merely guidelines that college admissions offices use to predict how well a student may perform in college; many other factors contribute to a student's ultimate performance, such as maturity level, hard work and determination, just to name a few. There are many examples of college students performing at a higher or lower level than their academic statistics would predict. In addition, if admissions were based solely on the basis of academic statistics, applicants who would be accepted in place of the student-athletes would have the lowest academic statistics in the entering class; even if academic statistics were perfectly predictive, which they are certainly not, those applicants would not perform significantly better than the student-athletes.

An additional weakness with Morgan's third justification for eliminating the Congressional presumption is that it is largely based on assumptions and statistics with respect to which there is wide disagreement. For example, statistics comparing the graduation rates of student-athletes with the student body as a whole have been hotly contested. In his response to Representative Bill Thomas, Myles Brand reported graduation rate statistics that were significantly different than those cited by Morgan, and he challenged the assumption that student-athletes do not satisfy the academic criteria established for students in general by asserting that Division I scholarship student-athletes, on average, have higher SAT scores and high school grade point averages than college students as a whole (Brand, 2006 pp. 10 and 12-13).

Morgan's proposal is to eliminate the Congressional presumption that college and university athletic programs are substantially related to the educational purposes of those institutions, and to replace it with a case-by-case factual inquiry into whether an athletic program of a particular college or university is substantially related to the educational purpose of the institution (Morgan, 2007 p. 189). He suggests factors that should be used to make that determination. First, he states that "the number, recency, and severity of NCAA or institutional rule infractions will be relevant" (p. 191). It is unclear exactly how rule infractions committed by an athletic program could be relevant in determining whether the program is substantially related to the educational purpose of the college or university, and he does not offer any explanation of that statement.

His second and third factors require comparing the academic performance and graduation rates of an athletic department's student-athletes with those of the general student body (p. 191). He asserts that if the grade point averages and graduation rates of student-athletes are significantly lower than those of the student body as a whole, "it is unlikely that education is being enriched through participation in athletics" and the athletic departments of those institutions "are not contributing 
importantly to the furtherance of education" (pp. 191-92). This conclusion substantially overstates the significance of academic performance of student-athletes to the question of whether a college or university's athletic programs contribute importantly to the accomplishment of the institution's educational purposes. As previously discussed, colleges and universities receive substantial benefits, educational and otherwise, from maintaining high-quality athletic programs. While the academic performance of an institution's student-athletes is somewhat relevant to the relationship of its athletic programs to its educational purpose and mission, it is just one factor, no more or less important than the many others discussed above.

Morgan's fourth suggested factor relates to a statement made in the Regulations with regard to determining whether a trade or business is substantially related to an organization's exempt purposes: if the trade or business is "conducted on a larger scale than is reasonably necessary for performance of" the organization's exempt functions, "the gross income attributable to that portion of the activities in excess of the needs of exempt functions constitutes gross income from the conduct of [an] unrelated trade or business" (Treas. Reg. § 1.513-1(d)(3)). He misapplies the Regulations by taking that sentence out of context to conclude that if an athletic program generates excessive profit it is being conducted on a larger scale than is reasonably necessary for performance of the college or university's educational functions, and thus is not substantially related to the institution's exempt purpose (Morgan, 2007 p. 192).

Morgan's emphasis on an athletic program's generation of profit in applying these Regulations is misguided; a more complete consideration of those Regulations allows for an accurate analysis. The sentence in the Regulations immediately before the statement used by Morgan in his fourth factor states that in determining whether a trade or business is substantially related to an organization's exempt purposes, an important factor is the "size and extent of the activities involved" in operating the trade or business compared with the "nature and extent of the exempt function which they purport to serve" (Treas. Reg. § 1.513-1(d)(3)). Next comes the statement used by Morgan: If the trade or business is "conducted on a larger scale than is reasonably necessary for performance of" the organization's exempt functions, "the gross income attributable to that portion of the activities in excess of the needs of exempt functions constitutes gross income from the conduct of [an] unrelated trade or business" (Treas. Reg. § 1.513-1(d)(3)). The Regulations are clearly discussing the activities involved in the trade or business, not the profit generated by such trade or business. The Regulations give no guidance on the question of when a trade or business would be considered to be conducted on a larger scale than is reasonably necessary for performance of the organization's exempt functions. If athletic programs are in fact related to the educational purposes of colleges and universities, it is difficult to imagine how the size and extent of the activities involved in conducting an athletic program could be greater than is reasonably necessary for performance of an institution's educational function.

These recent appeals to Congress to subject college and university athletic programs to the UBIT appear in reality to be at best a cry for increased and more effective regulation of such programs by the NCAA, and at worst a red herring aimed at gaining leverage in a quest to diminish the ever-widening influence of intercollegiate athletics in the world of higher education. Morgan, for example, asserts that "the NCAA has neither the power nor the ability to directly regulate 
the economic activities of its member institutions" (Morgan, 2007 p. 196). He argues that the threat of potential tax liability under the UBIT will incentivize athletic departments to recruit and admit student-athletes with adequate academic credentials, and insure that its student-athletes academically perform at a satisfactory level and graduate from the institution (pp. 195-96). The UBIT was never in any way intended to be a regulatory device for college or university athletic programs or for any other exempt organization; on the contrary, it was intended to address Congressional concerns that colleges and universities conducting trades or businesses were able to deprive the government of significant tax revenue from those business operations and to enjoy an unfair competitive advantage over commercial business entities required to pay taxes on their income. Moreover, the UBIT would be horrendously inefficient as a means of regulating those programs.

There is probably universal agreement that college and university athletic programs are in need of reform, and most would probably agree that the most competitive and profitable programs are in need of more effective regulation than they currently receive. But that falls far short of concluding that any programs currently in existence are not substantially related to the college or university's educational purpose. It would be difficult to envision an athletic program that would be so devoid of educational value that it would not contribute importantly to the educational purpose of a college or university; for that to be the case, the athletic program would have to be conducted similar to a professional sports franchise, with virtually no regard given to education of its student-athletes. No athletic program would be allowed to go that far if appropriate and effective regulation is administered by the NCAA. Part III of this article proposes an alternative means of Congressional legislative reform to ensure that no college or university athletic program becomes so unrelated to the educational purposes of the institution that it would become subject to the UBIT.

\section{Policy Analysis}

A recent article by Professor John Colombo proposes a different approach. He agrees that the current state of the law precludes withdrawal of the "tax exemption from either the NCAA or the individual universities that conduct Division I football and basketball programs," and it precludes application of the UBIT to the NCAA or to college and university athletic programs; in addition, he presents an insightful and well-documented argument that subjecting those institutions to the UBIT would make no difference, other than forcing them to incur significant additional expenditures to comply with the law, because there would ultimately be no net revenue to tax (Colombo, 2009 pp. 27 and 36). The NCAA distributes all its net revenues to member schools; those distributions would likely be a deductible expense for tax purposes, leaving little or no unrelated business taxable income that would be subject to the UBIT even if Congress somehow changed the law to make the UBIT applicable to the NCAA (p. 37). Similarly, most athletic programs of colleges and universities are not profitable, and the few programs that currently show a profit do so in large part because those colleges and universities have no existing incentive to use rigorous cost accounting principles with respect to those programs; application of such principles would require proper allocation of costs to each athletic program for its share of capital expenditures for buildings and equipment, maintenance of 
facilities, employee costs, and the like. Professor Colombo cites to James Shulman and William Bowen for their conclusion "that if capital costs are properly accounted for, no program would show an actual net profit for accounting purposes" (p. 38). In addition, if an individual program showed a profit even after proper application of cost accounting principles, it would not require very sophisticated tax planning methodologies to eliminate any unrelated business taxable income that might result. As aptly stated by Professor Colombo, "I doubt that the general counsel of, say, the University of Michigan would cower much in the face of a threat by the IRS to apply the UBIT to Michigan's football program" (p. 39).

Despite Professor Colombo's conclusions that the current state of the law precludes withdrawal of the tax exemption from the NCAA or college and universities conducting athletic programs, and precludes application of the UBIT to the NCAA or to those programs, and that subjecting those institutions to the UBIT would make no difference in any event because there would ultimately be no net revenue to tax, he nevertheless proposes that Congress change the law. He justifies his proposals by asserting that "big-time college athletics does not fit any of the theoretical explanations for tax exemption and does fit within the rationales for applying the UBIT[,]" and concludes that revenues from college and university athletic programs should thus be taxed as a matter of tax policy (p. 41).

Professor Colombo acknowledges that "there is no clearly-defined underlying theory for why we grant tax exemption to the broad range of organizations that claim charitable status[,]" but then discusses the various theories that have been offered over the years by academics and tax theorists to possibly justify such treatment and concludes that "big-time college athletics appears to fail under all of them." The theories he discusses all make various assumptions: examples include the role charities should play in society; and behavioral characteristics of individuals, organizations and government and their responsiveness to various stimuli (pp. 41-43). Needless to say, the hypotheses posited by these theorists are highly speculative and subject to disagreement. In addition, Professor Colombo recognizes that under current law it makes no practical difference in any event whether any of these theories support tax exemption for college or university athletic programs because all such programs constitute only a relatively minor portion of the activities of the college or university operating them, and "tax-exemption is applied to entities, not to individual activities of entities" (p. 45).

As explained by Professor Colombo, "the UBIT was enacted precisely to handle this kind of situation: that is, to tax revenues from commercial activities undertaken by an otherwise exempt charity." He describes the two principal justifications for adoption by Congress of the UBIT, as more fully discussed in Part II.B.1 of this article: "protecting the corporate tax base," which he believes is the most important, and "avoiding 'unfair competition' between charities and for-profit service providers." Regarding the latter, Colombo explains that "economists almost uniformly have rejected the notion that charities engage in 'unfair competition,' at least if one defines the term as some sort of predatory pricing or predatory market entry or expansion" (p. 46). He also describes two "policy concerns," one of which is to limit "the extent to which the attention of charitable managers is diverted from their core charitable mission to for-profit empire building." He asserts that " $[\mathrm{g}] \mathrm{g}$ iving Division I football and basketball revenues a pass under the UBIT clearly offends the corporate tax base protection and diversionary concerns ..." (pp. 45-47). 
Professor Colombo recognizes that little or no tax revenue would be collected by subjecting college and university athletic programs to the UBIT because "it is likely that only a few of these programs would show a taxable profit after applying rigorous tax-accounting policies to their income and expenses." As a result, it is difficult to understand how the corporate tax base could be at risk; but he insists that his point is nevertheless valid. He uses as an example the U.S. auto industry, and asserts that automakers should not receive a tax exemption simply because in recent years they have been unprofitable; "the theoretical tax base should include operations by auto manufacturers and the potential for future profit cannot be ignored" (p. 48 n.155). But an industry that is unprofitable in some years and profitable in others is clearly distinguishable from college and university athletic programs which, as Professor Colombo readily admits, will never show a profit. As to his diversionary concern, that theory is highly speculative and subject to disagreement. To the extent it has any validity, he fails to adequately explain how it is "offended" by current law. He baldly asserts that college and university athletic programs "may be the best example of how a significant commercial activity diverts the attention of charitable management from their core charitable program to the needs of the commercial business" (p. 48). To support this assertion, he argues that coaches are hired at increasingly exorbitant salaries to win games rather than provide education, substantial amounts of financial resources are spent on athletic training facilities and stadiums at the expense of the educational environment of the institution, and university administrators spend substantial amounts of time and money dealing with recruiting violations instead of educational endeavors. Those arguments are mostly conclusory and are subject to wide disagreement as previously discussed.

Based on his conclusions that "big-time college athletics does not fit any of the theoretical explanations for tax exemption and does fit within the rationales for applying the UBIT" (p. 41), Professor Colombo proposes three specific requirements Congress should impose on the NCAA or colleges and universities operating athletic programs: (1) Congress should "require that a certain percentage of revenues from revenue-producing sports such as football and basketball be used to expand nonrevenue athletic opportunities" (p. 51); (2) Congress should impose "targeted expenditure limits, such as capping coaches' salaries or limiting annual expenditures on recruiting or sports facilities" (p. 53); and (3) Congress should require "both the NCAA and universities with athletic programs to provide detailed information both on the financial aspects of their programs using standardized accounting methods and on the academic progress of student-athletes" (p. 4).

Whether all or any of these proposed requirements merit adoption by Congress is certainly debatable, and they may well have positive effects from a policy standpoint. Capping coaches' salaries may violate current antitrust laws, as discussed in the next section of this article. But the question here is how adoption of these requirements has anything to do with tax law. The answer suggested by Professor Colombo is that federal tax law be used to enforce them. He suggests subjecting the NCAA or college and university athletic programs to the UBIT for violating these requirements; as he correctly concludes, those institutions can easily avoid showing a profit and will avoid paying any tax under the UBIT whether they are subject to it or not. Instead, he suggests that these new rules "be structured as requirements for continued tax exemption of the [college or university] operating the sports program" (p. 51). In other words, he recommends that if a college or 
university violates these relatively minor rules that affect only its athletic programs it will lose its tax exemption applicable to the entire institution, an enforcement measure basically akin to capital punishment. Whether his proposed requirements are justified or not, they hardly merit such a draconian remedy.

Some of Professor Colombo's proposals appear meritorious, but care must be taken not to swing the pendulum so far in the opposite direction as to unduly punish educational institutions by changing federal tax laws that may have unintended adverse consequences. Enforcement measures for any new regulations deemed necessary should be specific and appropriate to the harm caused by their breach. In addition, it would be a mistake to further burden and complicate federal tax laws with new requirements to be met by the NCAA and its member educational institutions, along with creating the potentially significant costs of federal agency enforcement, when targeted reform can more effectively achieve some of these objectives and others in an alternative manner.

\section{"Myles Brand Student-Athlete Education and Welfare Act": Conditional Antitrust Immunity as an Effective Means of Implementing Targeted Reforms of Commercialized Intercollegiate Athletics}

The commercialization of intercollegiate athletics in response to culturally-driven market forces is a largely irreversible trend, which is not necessarily socially undesirable because it can be used to further broader university academic objectives. Some reform, however, is needed to ensure that the intercollegiate athletics are student-athlete centered and actually further the purpose of higher education, rather than functioning as a tail that wags the university dog or an anchor that inhibits fulfillment of its academic mission. In this section we propose that using the carrot of federal antitrust law immunity (rather than swinging the stick of threatened federal taxation of athletic department revenues) to implement targeted reforms to correct the most significant problems caused by the commercialization of intercollegiate athletics.

\section{Historical Application of Antitrust Law to NCAA Regulation of Intercollegiate Athletics and Proposed Reform}

According to the NCAA, "[s]tudent-athletes shall be amateurs in an intercollegiate sport, and their participation should be motivated primarily by education and by the physical, mental and social benefits to be derived. Student participation in intercollegiate athletics is an avocation, and student-athletes should be protected from exploitation by professional and commercial enterprises" (NCAA Manual, 2008-09, Bylaw 2.9). Professor Davis has aptly characterized this idealized view of intercollegiate athletics espoused by the NCAA as the "amateur/education" model (Davis, T., 1994 p. 270) However, as previously discussed, true "amateurism" is nonexistent, especially today when many student-athletes receive "compensation" for participating in intercollegiate sports in the form of an economically valuable athletic scholarship that covers the costs of their college tuition, room, board, and 
books. Nevertheless, this model may accurately encompass most intercollegiate athletics competition and student-athletes, particularly women's and men's sports that do not generate net revenues in excess of their production costs.

Those who participate in intercollegiate athletics are expected to strive for excellence in both academics and athletics, unlike professional athletes whose sole focus in on the later objective. Consistent with the educational component of the amateur/education model, student-athletes' participation in intercollegiate athletics does in fact have several academic and future career benefits. Analysis of data from a 2007 National Collegiate Athletic Association study of 8,000 former student-athletes reveals that: 1) $88 \%$ of student-athletes earn their baccalaureate degrees (compared with less than $25 \%$ of the American adult population); 2) $91 \%$ of former Division 1 student-athletes are employed full-time (11\% more than the general population), and on average, have higher income levels than nonstudent athletes; 3) 89\% of former student-athletes believe the skills and values learned from participating in intercollegiate athletics helped them obtain their current employment in a career other than playing professional sports ; and 4) $27 \%$ of former Division 1 student-athletes earn a postgraduate degree (Brown, 2007).

On the other hand, the "commercial/education" model, which "assumes that college sports is a commercial enterprise subject to the same economic considerations as any other industry," (Davis, T., 1994 p. 279) more accurately describes intercollegiate sports such as Division 1 FBS football and men's basketball. Universities' commercial exploitation of the entertainment value of these two enormously popular sports creates an inherent tension with their academic mission and the potential to overshadow or marginalize the educational aspects of intercollegiate athletics'. As former NCAA President Myles Brand observed: "there is rising concern that the values important to higher education have been overwhelmed by the popularity of intercollegiate athletics to media and marketing. As pressures to win and to generate revenue increase, the integration of athletics with the academy, the interference with presidential authority by avid fans or trustees, and the primacy of education in the student-athlete experience have all been threatened" (Brand, 2006 p.4).

NCAA rules that limit or regulate the commercial aspects of intercollegiate athletics currently are subject to the federal antitrust laws despite the nonprofit status of the NCAA and its member colleges and universities. The primary purpose of the antitrust laws is to preserve a competitive marketplace to ensure that consumers receive the benefits of economic competition. Joint agreements such as NCAA rules and regulatory activity that unreasonably restrain economic competition among its member universities or the intercollegiate athletics market violate antitrust law, specifically $\S 1$ of the Sherman Act (15 U.S.C. $\$ 1$ ).

In NCAA v. Board of Regents of the University of Oklahoma (1984), the U.S. Supreme Court ruled that NCAA rules limiting the number of college football games that its members could televise annually was an output market restraint that violated the antitrust laws, thereby implicitly recognizing the existence of a commercial/ education model for some aspects of intercollegiate athletics. The Court established a "rule of reason" framework for determining whether a challenged NCAA rule is reasonable (i.e., legal) or unreasonable (i.e., illegal), which requires consideration and analysis of both its anticompetitive and procompetitive effects to determine its net economic effects on competition in the relevant market. It concluded that 
jointly limiting the number of televised college football games below the level that would be supplied in a free market responsive to consumer demand has significant anticompetitive effects. This restraint did not further a legitimate procompetitive economic objective such as maintaining competitive balance among NCAA members' football teams. Although the Court suggested the antitrust laws should be judicially construed to provide the NCAA with "ample latitude" to maintain the "revered tradition of amateurism in college sports" and to preserve the "studentathlete in higher education," collectively limiting the number of televised college football games did not achieve these objectives.

Similarly, in Law v. NCAA (1998), a federal appellate court held that an NCAA rule limiting the yearly compensation of Division 1 entry-level basketball coaches (i.e., "restricted-earnings" coaches) to $\$ 16,000$ (a restraint on an input necessary to produce intercollegiate basketball) was an antitrust violation. The court found that the "obvious anticompetitive effects" of fixing the cost of an input necessary to produce intercollegiate athletics (e.g., coaching) prevented free market competition among NCAA universities for the services of coaches. In contrast to a rule "equaliz[ing] the overall amount of money Division 1 schools are permitted to spend on their basketball programs," which would be a procompetitive means of promoting competitive balance, capping the salaries of one category of coaches would not achieve this objective. The court ruled that "cost-cutting by itself is not a valid procompetitive justification" for price fixing, although market competition would lead to higher coaching salaries without this restraint. The coaches ultimately won a jury verdict of $\$ 22.3$ million, which was increased to $\$ 66.9$ million in mandatory treble damages. The NCAA subsequently settled the case for $\$ 54.5$ million in damages and approximately \$20 million in attorneys' fees and costs to plaintiffs' attorneys.

In contrast, courts have relied upon the "amateur/education" model of intercollegiate athletics to reject antitrust challenges to NCAA eligibility rules by student-athletes participating in highly commercialized sports such as Division 1 FBS football and men's basketball. For example, in Banks v. NCAA (1992), a federal appellate court held that the NCAA's "no agent" rule (a student-athlete loses eligibility to participate in all intercollegiate sports if he agrees to be represented by an agent) and its "no draft" rule (a student-athlete loses his amateur eligibility in a particular sport such as NFL football if he asks to be placed on a professional league's draft list for the sport) do not violate the antitrust laws. The court concluded that both rules legitimately preserve the amateur nature of intercollegiate athletics, and that the "no draft" rule achieves the precompetitive objective of maintaining "the clear line of demarcation between college and professional football."

Other courts also have disregarded the commercialized nature of Division 1 FBS football and men's basketball by ruling that NCAA rules seeking to maintain the "amateur" nature of intercollegiate athletics are essentially per se legal for purposes of antitrust law. This judicial view appears based on the unproven assumption that the significant popularity and commercial success of intercollegiate athletics is primarily attributable to this self-serving NCAA characterization, thereby demonstrating their responsiveness to consumer demand as required by antitrust law. Thus, a broad range of NCAA rules to preserve amateurism (e.g., prohibiting any price competition among universities or payment of fair market wages for their athletic services or the receipt of athletics-related pecuniary benefits from nonfa- 
mily third parties) are legal regardless of any adverse effects on student-athletes' economic interests.

In Board of Regents, the Supreme Court observed that "[t]he NCAA is an association of schools that compete against each other to attract television revenues, not to mention fans and athletes." Scholarly commentary generally has been very critical of lower court cases such as Banks for inappropriately presuming that NCAA amateurism rules are a noncommercial restraint not subject to antitrust scrutiny or a predominantly procompetitive form of internal regulation necessary to produce intercollegiate athletics (Lazaroff, 2007; Mitten, 1995). One scholar has asserted: "Courts should abandon anachronistic precedent based on unrealistic ideals of the 'amateur' nature of 'big-time' college athletics and develop a principled antitrust jurisprudence more consistent with the economic realities of college sports in the $21^{\text {st }}$ century" (Mitten, 2000). Thus, rather than relying on an outdated amateur/ education model to reach a contrary conclusion, courts should characterize NCAA amateurism rules as restraints on economic competition among universities for student-athletes' services, which should be subject to rigorous antitrust scrutiny under the Board of Regents rule of reason framework.

Because of NCAA rules prohibiting any price competition for student-athletes' services, universities incur artificially reduced "labor" costs to produce sports such as Division 1 FBS football and men's basketball and garner economic rent. These cost savings in turn are used to fund socially desirable objectives (e.g., subsidizing the costs of producing female and male intercollegiate sports that do not generate net revenues) or undesirable ones (e.g., paying exorbitant annual salaries in excess of \$1 million to head coaches in revenue generating sports) (Rascher and Schwarz, 2000). In addition, NCAA amateurism rules have the unintended consequence of contributing to the athletic arms' race by encouraging inefficient nonprice competition for student-athletes' services.

Recently, two different groups of former student-athletes have brought class action antitrust litigation against the NCAA in an effort to obtain a share of the revenues generated by their playing abilities and fame than historically has been permitted under NCAA rules. In O'Bannon v. NCAA (2009), the plaintiffs alleged that the NCAA's member universities and others collectively refused to permit former Division 1 basketball players and FBS football players to share in the multimillion dollar revenues from the sale of products incorporating their likenesses-even after their intercollegiate athletics eligibility ended-in violation of the antitrust laws. This case currently is pending in a California federal court.

In White v. NCAA (2006), a group of former Division I-A football and Division I basketball players asserted that an NCAA rule limiting the maximum value of their football and basketball scholarships to the value of tuition, fees, room and board, and books (which is approximately $\$ 2,500$ to $\$ 3,000$ less than the full annual cost of attending college) violates antitrust law. The complaint was carefully drafted in an effort to avoid the NCAA's defense that this rule is necessary to preserve the amateur nature of intercollegiate athletics. Although the court ruled that plaintiffs' complaint sufficiently alleged an anticompetitive agreement among NCAA member universities to fix the economic value of their athletic scholarships, this case subsequently was settled before trial. The settlement terms required the NCAA to make available a total of $\$ 218$ million to Division 1 institutions to provide aid to current student-athletes with financial and/or academic needs; to establish a $\$ 10$ 
million fund to reimburse plaintiffs' future education expenses; to permit Division 1 institutions to provide student-athletes with insurance for sport-related injuries and year-round health insurance; and to consider legislation permitting multiyear student-athlete scholarships and financial aid through graduation to student-athletes who no longer qualify for athletic-based aid.

Despite the historical judicial refusal to apply antitrust law to NCAA restraints that adversely affect student-athletes' economic interests, White and O'Bannon illustrate that the potential recovery of mandatory treble damages and attorneys' fees creates significant incentives for class action antitrust litigation against the NCAA. The risk of potential significant liability if plaintiffs prevail on the merits of their antitrust claims creates a strong NCAA incentive to reach a monetary settlement, which only resolves the immediate problem by making a one-time wealth transfer providing only short term, limited additional economic benefits to some studentathletes. But a settlement does not remedy the underlying problems giving rise to student-athletes' antitrust claims or preclude future antitrust litigation by others, the risk of which may inhibit NCAA internal reform to ensure that the revenues generated by commercialized sports more effectively further a university's academic mission and student-athletes' welfare.

Effective NCAA internal governance of commercialized intercollegiate athletics requires uniform rules and enforcement, which are necessarily the product of agreements and collective decision-making among NCAA member institutions, thereby inviting antitrust challenges under $\S 1$ of the Sherman Act. However, antitrust law is prohibitory in nature and is not well-suited to externally regulating NCAA internal governance of intercollegiate athletics, particularly rules and agreements that define this unique brand of athletic competition and the permissible scope of a university's relationship with its student-athletes. Moreover, a piecemeal approach by way of antitrust litigation that merely considers the legality of the particular challenged restraint (which may result in judicial invalidation of some NCAA rules with socially desirable effects) will not effectively solve macro, systemic problems inherent in the production of commercialized intercollegiate athletics by institutions of higher education. The primary actual and potential problems caused by this blend of athletics and academics are an overemphasis on winning and generating sports-related revenues; a misallocation of scare university resources to the athletic department; subordination of higher education academic values to the forces of commercialization; and student-athletes' inability to realize the educational benefits of the quid pro quo for providing playing services.

We propose that Congress provide the NCAA and its member institutions with immunity from antitrust liability under $\S 1$ of the Sherman Act (but not $\S 2$ of the Sherman Act, which prohibits monopolization and attempted monopolization) conditioned upon the adoption and implementation of several targeted external reforms to ensure that 21 st century intercollegiate athletics furthers legitimate higher education objectives, provides student-athletes with the full benefits of their bargain, and enhances the likelihood they will obtain a college education that maximizes their future career opportunities other than playing professional sports. By eliminating the threat of potential antitrust liability under $\S 1$ of the Sherman Act, this limited exemption would enable the NCAA and its member institutions to adopt internal reforms that prevent intercollegiate athletics from crossing the line 
between a primarily educational to a commercial endeavor; enhance the academic integrity of intercollegiate athletics; promote more competitive balance in intercollegiate sports competition; require university fiscal responsibility rather than an athletics arms race; and limit unbridled market competition for inputs necessary to produce intercollegiate athletics such as coaches.

\section{Proposed Conditional Antitrust Immunity and Potential Beneficial Effects}

We recommend that a new federal law immunizing the NCAA and its member institutions from antitrust liability under $\S 1$ of the Sherman Act be titled the "Myles Brand Student-Athlete Education and Welfare Act" in honor of former NCAA President Myles Brand, who died on September 16, 2009. A philosophy professor, Brand was the first university president to serve as NCAA president. He was a strong proponent of commercialized intercollegiate athletics who believed that they are an integral part of higher education, but his advocacy for NCAA reforms to better integrate athletics and academics and to enhance student-athletes' educational experiences and welfare was equally vigorous.

Our proposed antitrust immunity would be conditioned upon certain requirements that the NCAA and/or its member institutions must satisfy to ensure that commercialized intercollegiate athletics are primarily an educational endeavor and that student-athletes in sports that generate net revenues receive valuable educational benefits in exchange for their playing services. The following are some possible requirements that could be imposed as conditions of our proposed antitrust immunity:

1) At least a four-year athletic scholarship that covers the full annual cost of college attendance (which may be taken away only for failing to meet minimum academic requirements, engaging in misconduct, or voluntarily choosing to discontinue playing a sport) with tuition funding for a fifth or sixth year of college education if necessary to complete a bachelor's degree provided the student-athlete is in good academic standing when his or her intercollegiate athletics ability is exhausted. Providing these additional benefits would appear to have a strong potential for increasing the college graduation rates of Division 1 FBS football and men's basketball student-athletes. A recent analysis of Federal Graduation Rate data evidences that "student-athletes graduate (within 6 years) at higher or similar rates than do their nonathletic counterparts." (Kane, Leo, and Holleran, 2008, p. 101). College graduates generally earn more income during their working career than those who have not earned their degree (Marburger and Hogshead-Makar, 2003), so it is important for student-athletes who play football or basketball to graduate from college because of the very low likelihood they will earn a living playing these sports professionally.

2) Free medical care or health insurance for all sports-related injuries plus extension of the injured student-athlete's scholarship for a period of time equal to the time he is medically unable to attend class due to injury. This is an important benefit because the NCAA currently permits but does not require its member institutions to provide medical care or health insurance 
for sports-related injuries. In addition, courts generally hold that studentathletes, including those that participate in net revenue generating sports, are not "employees" entitled to recover worker's compensation benefits for these injuries.

3) Mandatory remedial assistance and tutoring for entering student-athletes whose indexed academic credentials are below a certain percentile (e.g., 25th) for their university's freshman class. The NCAA's Academic Progress Rate system that holds universities accountable for their students-athletes' collective academic performance and imposes penalties for deficiencies currently provides an incentive to voluntarily provide these services, but mandating such assistance likely would enhance the academic performance of individual students-athletes most at risk for not succeeding academically.

4) The creation of a postgraduate scholarship program administered by the NCAA and funded by a certain percentage of the total net revenues generated by intercollegiate football and men's basketball (and perhaps other sports), including the sales of merchandise incorporating aspects of student-athletes' persona (e.g., team jerseys with numbers identifying popular individual players). Because the collective efforts of all participating student-athletes, including those who are less prominent or talented, are necessary to produce each of these sports and contribute to an individual player's commercial popularity, all of them should have the opportunity to qualify for educational benefits funded by the commercial exploitation of publicity rights.

There is justification for providing greater educational benefits to studentathletes playing net revenue generating sports such as Division 1 men's basketball and FBS football. One legal scholar observes that student-athletes who participate in major college basketball and football "are doing something special for their schools" by providing the university with a vital link to alumni, bringing together diverse constituencies, and creating contagious euphoria. He asserts that "[t]hose who provide the occasions for collective euphoria are making a unique contribution to the [university] community and deserve to be recognized for it" (Wheeler, 2004 p. 229).

In attempting to discern why graduation rates for student-athletes in Division 1 men's basketball and FBS football historically have been below male graduation rates for the general student body, other scholars suggest one plausible explanation: "coaches in men's basketball and football at this level demand more of them, in terms of time and energy, than athletes in other programs. While this assertion is speculative because there is little empirical data available in this important area, it makes sense that coaches at this level, who are better paid and are under extreme pressure to win because profits are tied to winning programs, demand more of their players, in order to retain their position, salary and benefits" (Smith and Walker, 2001, p. 168). They note that these student-athletes are predominantly persons of color whose athletic abilities generate substantial revenues that fund other intercollegiate sports in which the participating student-athletes are not. Smith and Walker contend there is "a strong argument that they are not receiving an equitable share of the wealth they contribute to generating" (p. 167). Because providing greater educational benefits to student-athletes in net revenue-generating sports such as men's football and basketball is facially gender neutral, they suggest that doing 
so may not violate Title IX gender equity laws because "this is really an equal pay for equal work claim, like that of women coaches who have [unsuccessfully] challenged the differential in compensation between themselves and coaches in men's sports" (p. 197).

Antitrust immunity could also be conditioned upon adoption of some of Professor Colombo's foregoing proposals, particularly requiring that a certain percentage of the net revenues from sports such as football and men's basketball be used to fund and expand participation opportunities for student-athletes in sports that do not generate net revenues, or requiring the NCAA and its member universities to provide detailed information concerning their athletic department finances using standardized accounting methods. Some members of Congress may insist on conditioning antitrust immunity on the dismantling of the current Division 1 FBS system, which favors universities in Bowl Championship Series conferences, and the establishment of a national championship playoff system in which all universities with Division 1 FBS football teams have an equal opportunity to participate.

Congressionally provided antitrust immunity from $\$ 1$ of the Sherman Act would enable the NCAA and its member universities to pursue important socially desirable objectives, some of which otherwise would violate the antitrust laws. For example, NCAA legislation to limit the athletics' arms race by imposing annual or multiyear per sport aggregate spending caps or limits on certain expenditures (e.g., coaches' salaries) could be adopted for the different levels of intercollegiate athletics competition (e.g., Division I, II, and III). The Law case currently limits NCAA member institutions' collective ability to control escalating university expenditures on intercollegiate athletics costs, which in recent years have increased at a rate two to three times more than other higher education expenditures and increasingly require universities to financially subsidize their athletic departments. Antitrust immunity also would facilitate universities' ability to maintain or increase intercollegiate athletics participation opportunities in women's sports and men's nonrevenue sports by subsidizing the costs of their production from net revenues generated by other sports (primarily men's basketball and football) without fear of antitrust litigation.

\section{Conclusion}

Legend has it that King Canute I was the ancient monarch who stood on the ocean shore and commanded the tide not to come in - not surprisingly, his effort failed. Similarly, the commercialization of intercollegiate athletics is an inevitable market response to our nation's strong cultural passion for sports competition. It is equally inevitable that college and university leaders would seek to use intercollegiate athletics as a means of achieving other legitimate institutional objectives. Because intercollegiate athletics are an integral part of institutions of higher education, the revenues generated by university athletic departments should continue to be exempt from federal taxation. It is, however, necessary to ensure that the increasing commercialization of intercollegiate athletics does not conflict with the academic missions of universities or interfere with student-athletes' educational opportunities. Our proposed solution is that Congress should provide the NCAA and its member universities with a limited exemption from the federal antitrust laws as a means of 
implementing targeted reforms to ensure that intercollegiate athletics are primarily an educational endeavor rather than commercialized quasi-professional sports.

\section{References}

Alesia, M. Historians Debate roosevelt's ncaa legacy; president played key role in birth of organization, But 1905 'Ultimatum' Questioned, Indianapolis Star. (2006, January 7). $1 \mathrm{D}$

Awtrey, S. (2008, June 11). Georgia state hires Bill Curry as first coach. Atlanta Journal Constitution. Retrieved October 15, 2009, from http://www.ajc.com/sports/content/ sports/stories/2008/06/11/curry_0612.html

Banks v. NCAA, 977 F.2d 1081 (9 $9^{\text {th }}$ Cir. 1992).

Berkow, I. (1987, February 12). Sports of the times: Honest Abe had athletic ability, N.Y. Times, at B29

Bonime, W. (1986). Competitiveness and human potential. The Journal of the American Academy of Psychoanalysis, 14, 149-166.

Brand, M. (2006, November 13). Letter to Rep. Bill Thomas, Chairman, House Comm. on Ways and Means. Retrieved October 15, 2009, from http://www2.ncaa.org/portal/ media and events/press room/2006/november/20061115 response to housecommitteeonwaysandmeans.pdf.

Brand, M. (2006, October) Letter of Transmittal. National Collegiate Athletic Association. The Second Century Imperatives: Presidential Leadership—-Institutional Accountability, A Report From the Presidential Task Force on the Future of Division 1 Intercollegiate Athletics.

Brown, S. (2009) National Institute for Play. Retrieved October 15, 2009 from http://www. nifplay,org/sbrowncv.html

Brown, S. (2009). Interview regarding Dr. Brown's current research results. Retrieved October 15, 2009 from http://speakingoffaith.publicradio.org/programs/2009/play/

Brown, G.T. (2007, February 12). Research validates value and values of athletics. The NCAA News, 1.

Carter, B.W. (2006). The age of innocence: the first 25 years of the national collegiate athletic association, 1906 to 1931. Vanderbilt Journal Entertainment \& Technology Law, 8, 211-291.

Class Action Complaint, O'Bannon v. NCAA, CV09-3329 (N.D. Cal., filed July 21, 2009).

Colombo, J.D. (2009). The NCAA, tax exemption and college athletics. http://ssrn.com/ abstract $=1336727,1-59$.

Congressional Budget Office (CBO). (2009, May). Tax preferences for collegiate sports. Crowley, J. N. The ncaa's first century. Retrieved October 15, 2009 from http:// www.ncaapublications.com/Uploads/PDF/in_the_arenaaeaf7293-fb6f-4938-9b6fab04197eb89f.pdf

Davenport, J. (1999). From Crew to Commercialism - the Paradox in Higher Education, Sports and the Law: A Modern Anthology. CAROLINA ACADEMIC PRESS.

Davis, T. (1994). Intercollegiate athletics: competing models and conflicting realities. Rutgers Law Journal, 25, 269-327.

Emerson, A. (2007, October 1). USF officials prepare for perks of success. The Tampa Tribune. Retrieved October 15, 2009, from http://www2.tbo.com/content/2007/oct/01/ usf-officials-prepare-perks-success/sports-colleges-bulls/.

Griffith, J.L. (1930) The Carnegie Reports: Another View of The Study of Intercollegiate Athletics Made by The Carnegie Foundation, J. of Higer Educ., June 1930, in Vol. 1, No. 6, at 325-330.

House of Representatives Report (H.R. Rep.) No. 2319, $81^{\text {st }}$ Cong., 2d Sess. (1950), reprinted in 1950-2 C.B. 380. 
Internal Revenue Code (I.R.C.) § 170 (1986).

Internal Revenue Code (I.R.C.) § 501(a) (1986).

Internal Revenue Code (I.R.C.) § 501(c)(3) (1986).

Internal Revenue Code (I.R.C.) § 511(a) (1986).

Internal Revenue Code (I.R.C.) § 511(a)(2)(b) (1986).

Internal Revenue Code (I.R.C.) § 512 (a)(1) (1986).

Internal Revenue Code (I.R.C.) § 513(a) (1986).

Internal Revenue Service Revenue Ruling (Rev. Rul.) 80-295, 1980-2 C.B. 194 (1980).

Internal Revenue Service Revenue Ruling (Rev. Rul.) 80-296, 1980-2 C.B. 195 (1980).

Internal Revenue Service Technical Advice Memorandum (Tech. Adv. Mem.) 78-51-002 (1978).

Internal Revenue Service Technical Advice Memorandum (Tech. Adv. Mem.) 78-51-004 (1978).

Internal Revenue Service Technical Advice Memorandum (Tech. Adv. Mem.) 78-51-005 (1978).

Internal Revenue Service Technical Advice Memorandum (Tech. Adv. Mem.) 78-51-006 (1978).

Jensen, E.M. (1987). Taxation, the student athlete, and the professionalization of college athletics. Utah Law Review, 1987, 35-58.

Kane, M.J., Leo, P., \& Holleran, L.K. (2008). Issues related to academic support and Division I student-athletes: A case study at the University of Minnesota. Journal of Intercollegiate Sport, 1(1), 98-129.

Kaplan, R.L. (1980). Intercollegiate athletics and the unrelated business income tax. Columbia Law Review, 80, 1430-1473.

Kennedy, J.S. (2000, October 8). Rutgers-Princeton rivalry started college football tradition in 1869, Philadelphia Inquirer, MC6.

Law v. NCAA, 134 F.3d 1010 (10 ${ }^{\text {th }}$ Cir. 1998).

Lazaroff, D.E. (2007). The NCAA in its second century: defender of amateurism or antitrust recidivist? Oregon Law Review, 86, 329-372.

Lederman, D. (2008, May 20). Flocking to football. Inside Higher Ed. Retrieved October 15, 2009, from http://www.insidehighered.com/news/2008/05/20/football

Marburger, D.R., \& Hogshead-Makar, N. (2003). Is title IX really to blame for the decline in intercollegiate men's nonrevenue sports? Marquette Sports Law Review, 14, 65-93.

Mitten, M.J. (1995). University price competition for elite students and athletes: illusions and realities. South Texas Law Review, 36, 59-83.

Mitten, M.J. (2000). Applying antitrust law to NCAA regulation of 'big time' college athletics: the need to shift from nostalgic $19^{\text {th }}$ and $20^{\text {th }}$ century ideals of amateurism to the economic realities of the $21^{\text {st }}$ century. Marquette Sports Law Review, 11, 1-7.

Moltz, D. (2009, May 15). Athletic revival. Inside Higher Ed. Retrieved October 9, 2009, from www.insidehighered.com/layout/set/print/news/2009/05/15/roosevelt

Morgan, G.A. (2007). No more playing favorites: reconsidering the conclusive congressional presumption that intercollegiate athletics are substantially related to educational purposes. S. Cal. L. Rev., 81, 149-197.

Musselman, J.L. (2003). Recent federal income tax issues regarding professional and amateur sports. Marquette Sports Law Review, 13, 195-212.

NCAA v. Commissioner, 914 F.2d 1417 (10 ${ }^{\text {th }}$ Cir. 1990).

NCAA v. Board of Regents of the University of Oklahoma, 468 U.S. 85 (1984).

National Collegiate Athletic Association. (2009, May). The empirical effects of collegiate athletics: an update based on 2004-2007 data. Retrieved October 15, 2009, from http://web1.ncaa.org/web_files/DI_MC_BOD/DI_BOD/2009/April/04,\%20_Empirical_Effects.pdf.

National Collegiate Athletic Association. The history of the NCAA. Retrieved October 15, 2009 from http://www.ncaa.org/wps/ncaa?ContentID=1354. 
National Collegiate Athletic Association. (2006, October). The second century imperatives: presidential leadership - institutional accountability, a report from the presidential task force on the future of division 1 intercollegiate athletics

National Collegiate Athletic Association. (2006). 2004-06 NCAA Revenues and Expenses of Division 1 Intercollegiate Athletics Programs Report. Indianapolis: NCAA. Retrieved October 15, 2009, from http://www.ncaapublications.com/Uploads/PDF/NCAA_Revenues_Expenses.pdf798f201d-c82a-4cb3-9b05-e845a3cf24ec.pdf.

Norton, R.J. Abraham Lincoln took on the town bully!: at New Salem in 1831 he wrestled Jack Armstrong next to Denton Offutt's store. Retrieved October 15, 2009 from http:// home.att.net/ rjnorton/Lincoln48.html

Notice of Class Action Settlement and Fairness Hearing, White v. NCAA, CV06-0999 (C.D. Cal., filed February 4, 2008).

Rascher, D.A. and Schwarz, A.D. (2000, Spring). Neither reasonable nor necessary: "amateurism" in big-time college sports. Antitrust, 14, 51-56.

Revenue Revision of 1950: Hearings Before the House Comm. on Ways and Means (House Hearings), $81^{\text {st }}$ Cong. 2d Sess. 19 (1950) (remarks of Rep. Dingell).

Sander, L. (2008, September 19). Athletics raises a college from the ground up. Chronicle of Higher Education. Retrieved October 15, 2009, from http://chronicle.com/weekly/ v55/i04/04a00101.htm?utm_source=at\&utm_medium=en

Savage, H.J. (1929). Carnegie report: American college athletics, bulletin no. 2. New York: The Carnegie Foundation for the Advancement of Teaching.

Second Amended Complaint, White v. NCAA, CV06-0999 (C.D. Cal., filed September 18, 2006).

Senate Report (S. Rep.) No. 2375, 81 $8{ }^{\text {st }}$ Cong., 2d Sess. (1950), reprinted in 1950-2 C.B. 483.

Sherman Act, 15 U.S. C. $\$ 1$.

Sherman Act, 15 U.S. C. §2.

Shropshire, K. (1991). Legislation for glory of sport: amateurism and compensation. Seton Hall Journal of Sports Law, 1, 7-27.

Smith, R.K. (2000). A brief history of the NCAA's role in regulating intercollegiate athletics. Marquette Sports Law Review, 11, 9-22.

Smith, R.K., \& Walker, R.D. (2001). From inequity to opportunity: keeping the promises made to big-time intercollegiate student-athletes. Nevada Law Journal, 1, 160-201.

Smith, W.T., III. (2000, March 30). Tribute to flying wedge a starting point for ncaa's hall, USA Today. 7C

Sperber, M. (1993) Shake Down the Thunder: The Creation of Notre Dame Football (Indiana University Press 2002).

Steeg, J.L. (2007). Boise State Fiesta Goes On: Ticket Sales, Fundraising, Marketing Booming. USA Today, $\mathrm{C} 1$.

Thrash, R. (2007, September 28). Now nation knows who the bulls are. St. Petersburg Times. Retrieved October 15, 2009 from http://www.sptimes.com/2007/09/28/Hillsborough/ Now_nation_knows_who_.shtml

Treasury Regulation (Treas. Reg.) § 501(c)(3)-1(b)(1)(i).

Treasury Regulation (Treas. Reg.) § 501(c)(3)-1(c)(1).

Treasury Regulation (Treas. Reg.) § 501(c)(3)-1(d)(1)(ii).

Treasury Regulation (Treas. Reg.) § 501(c)(3)-1(e)(1).

Treasury Regulation (Treas. Reg.) § 513-1(d)(2).

Treasury Regulation (Treas. Reg.) § 513-1(d)(3).

Turano, C. The rise of intercollegiate football and its portrayal in American popular literature. Retrieved October 15, 2009 from http://www.uga.edu/honors/curo/juro/2001_10_13/ Turano3.html.

Wheeler, S. (2004). Rethinking amateurism and the NCAA. Stanford Law \& Policy Review, $15,213-235$. 